This PDF is a selection from an out-of-print volume from the National Bureau of Economic Research

Volume Title: Productivity Growth in Japan and the United States

Volume Author/Editor: Charles R. Hulten, editor

Volume Publisher: University of Chicago Press

Volume ISBN: 0-226-36059-8

Volume URL: http://www.nber.org/books/hult91-1

Conference Date: August 26-28, 1985

Publication Date: January 1991

Chapter Title: Bilateral Models of Production for Japanese and U. S. Industries

Chapter Author: Dale W. Jorgenson, Hikaru Sakuramoto, Kanji Yoshioka, Masahiro Kuroda

Chapter URL: http://www.nber.org/chapters/c8443

Chapter pages in book: (p. 59 - 83) 


\section{Bilateral Models of Production for Japanese and U.S. Industries}

Dale W. Jorgenson, Hikaru Sakuramoto, Kanji Yoshioka, and Masahiro Kuroda

\subsection{Introduction}

The purpose of this paper is to present bilateral models of production for 28 Japanese and U.S. industries for the period 1960-79. We treat data on production for the two countries as separate sets of observations. However, we assume that these observations are generated by an econometric model with common parameters. This model determines the distribution of the value of output among capital, labor, and intermediate inputs in each country. It also determines rates of technical change for both countries and the difference between the level of technology in the two countries.

Our methodology is based on the economic theory of production. The underlying model of production is the same as that employed in a companion paper by Jorgenson and Kuroda (this volume). We utilize this model in generating an econometric model of producer behavior for individual industries. Jorgenson and Kuroda employ the model to generate index numbers of productivity growth and differences in productivity between Japan and the United States. We use these indices as data, together with prices and quantities of output and inputs for each industry in modeling production.

Our models of production are based on the bilateral translog model introduced by Jorgenson and Nishimizu (1978). The point of departure for these models is a production function for each industry, giving output as a function of capital, labor, and intermediate inputs, a dummy variable equal to zero for the United States and one for Japan, and a time trend. The dummy variable allows for productivity differences between the two countries, while the time trend permits technology in each country to change from period to period.

Dale W. Jorgenson is a professor of economics at Harvard University. Hikaru Sakuramoto is a professor of economics, Faculty of Business and Commerce, Keio University. Kanji Yoshioka is a professor of economics, Keio Economic Observatory, Keio University. Masahiro Kuroda is a professor of economics, Faculty of Business and Commerce, Keio University. 
In analyzing differences in each industry's production patterns between the two countries, we combine the production function with necessary conditions for producer equilibrium. We express these conditions as equalities between shares of input in the value of output and the elasticity of output with respect to that input. The elasticities depend on input levels, the dummy variables for each country, and time. For given input intensities and given levels of technology, we find that U.S. industries have higher rates of labor remuneration than the corresponding Japanese industries. Japanese industries have higher rate of remuneration for capital and intermediate inputs. Technical change is predominantly capital saving, labor saving, and intermediate input using in both countries.

An important focus for our bilateral models of production is the difference between rates of technical change in Japanese and U.S. industries. For six of the 28 industries, we find that rates of technical change are higher in the United States than in Japan at given relative input intensities. Rates of technical change are higher in Japan for the remaining 22 industries. An alternative and equivalent interpretation of these results can be given in terms of the difference in technology between the two countries or the "technology gap." The technology gap between Japan and the United States is increasing for 22 of the industries included in our study and decreasing for only six industries. For industries where the United States has an advantage, the gap is closing; for industries where Japan has an advantage, the gap is widening.

Our industry classification is based on that of Jorgenson and Kuroda (in this volume). The Japanese industries are classified among 31 industries, while the U.S. industries are classified among 35 industries. In estimating our bilateral production model, we have consolidated the two classifications to 28 industries. In section 2.2, we provide a theoretical framework for our bilateral models of production. Section 2.3 outlines the empirical results, and section 2.4 provides a brief summary and conclusion. We present additional details on the constraints that must be satisfied by the parameters of our econometric models in order to meet the requirements imposed by the theory of production presented below in appendix A. The detailed empirical results are presented in appendix B.

\subsection{Theoretical Framework}

We treat data on production patterns for Japan and the United States as separate sets of observations. We assume that these observations are generated by an econometric model with common parameters. We describe the implications of the theory of production in terms of a bilateral production function for each sector. These functions are homogeneous of degree one, nondecreasing, and concave in capital, labor, and intermediate inputs.

In representing our bilateral models of production we employ the same notation as Jorgenson and Kuroda (in this volume). To characterize producer 
behavior in greater detail we introduce share elasticities with respect to quantity, ${ }^{1}$ defined as derivatives of the vectors of value shares $\left(v^{i}\right)$ with respect to vectors of logarithms of the inputs $\left(\ln X_{i}\right)$ :

$$
\frac{\partial v_{i}}{\partial \ln X_{i}}=\frac{\partial^{2} \ln Z_{i}}{\partial \ln X_{i} \partial \ln X_{i}^{\prime}}=\mathrm{B}_{X X}^{i}, \quad(i=1,2, \ldots, I),
$$

where $\ln Z_{i}(i=1,2, \ldots, I)$ is the logarithm of output in the $i$ th sector.

For the translog production functions the share elasticities $\left\{\mathrm{B}_{x x}^{i}\right\}$ are constant. We can also characterize these production functions as constant share elasticity (CSE) production functions, indicating the role of fixed parameters. ${ }^{2}$ If a share elasticity is positive, the value share increases with the input. If a share elasticity is negative, the value share decreases with the input. Finally, if a share elasticity is zero, the value share is independent of the input.

Continuing with a detailed characterization of producer behavior we define biases of technical change with respect to quantity as derivatives of the value shares with respect to time $T:^{3}$

$$
\frac{\partial v_{i}}{\partial T}=\frac{\partial \ln Z_{i}}{\partial \ln X_{i} \partial T}=\beta_{X T}^{i}, \quad(i=1,2, \ldots, I),
$$

Alternatively, we can define these biases as derivatives of the rates of technical change $\left(v_{T}^{i}\right)$ with respect to logarithms of the inputs. These two definitions are equivalent. For translog production functions the biases of technical change $\left(\beta_{x T}^{i}\right)$ are constant.

If a bias of technical change is positive, the corresponding value share increases with technology; we say that technical change is input using. If a bias is negative, the value share decreases with technology and technical change is input saving. Finally, if a bias is zero, the value share is independent of technology and we say that technical change is neutral. Alternatively, biases of technical change contain the implications of changes in inputs for the rate of technical change. If a bias is positive, the rate of technical change increases with the corresponding input. If a bias is negative, the rate of technical change decreases with the input. Finally, if a bias is zero, the rate is independent of the input.

Similarly, we define biases of the difference in technology with respect to quantity as derivatives of the value shares with respect to the dummy variable $D,{ }^{4}$ equal to zero for the United States and one for Japan.

$$
\frac{\partial v_{i}}{\partial D}=\frac{\partial^{2} \ln Z_{i}}{\partial \ln X_{i} \partial D}=\beta_{x D}^{i}, \quad(i=1,2, \ldots, I),
$$

Alternatively, we can define these biases as derivatives of the differences in technology $\left(v_{D}^{i}\right)$ between Japan and the United States with respect to logarithms of the inputs. These two definitions are equivalent. For the translog production functions the biases of differences in technology $\left(\beta_{x D}^{i}\right)$ are constant. 
If a bias of the difference in technology is positive, the corresponding value share increases between the United States and Japan and we say that the difference in technology is input using. If a bias is negative, the value share decreases between the United States and Japan and the difference in technology is input saving. Finally, if a bias is zero, the value share is the same in the United States and Japan and we say that the difference in technology is neutral. Alternatively, the vectors of biases of differences in technology contain the implications of changes in inputs for the difference in technology between the United States and Japan. If a bias of the difference in technology is positive, the difference in technology increases with the input. If a bias is negative, the difference in technology decreases with the input. Finally, if a bias is zero, the difference in technology is independent of the input.

Finally, we can define the biases of technical change with respect to the difference in technology between Japan and the United States as the derivatives of the rates of technical change $\left(v_{T}^{i}\right)$ with respect to the dummy variable: ${ }^{5}$

$$
\frac{\partial v_{D}^{i}}{\partial T}=\frac{\partial^{2} \ln Z_{i}}{\partial T \partial D}=\frac{\partial v_{T}^{i}}{\partial D}=\beta_{T D}^{i}, \quad(i=1,2, \ldots, I) .
$$

Alternatively, we can define these biases as the derivatives of the differences in technology $\left(v_{D}^{i}\right)$ with respect to technology. The two definitions are equivalent.

For the translog production functions the biases $\left(\beta_{T D}^{i}\right)$ are constant. If the bias is positive, the difference in technology increases with technology; correspondingly, the rate of technical change increases between the United States and Japan. If the bias is negative, the difference in technology decreases with technology; correspondingly, the rate of technical change decreases between the United States and Japan. Finally, if the bias is zero the difference in technology is independent of technology and the rate of technical change is the same for the United States and Japan.

To complete the description of technical change we can define the acceleration of technical change as the derivative of the rate of technical change with respect to technology:

$$
\frac{\partial v_{T}^{i}}{\partial T}=\frac{\partial^{2} \ln Z_{i}}{\partial T^{2}}=\beta_{T T}^{i}, \quad(i=1,2, \ldots, I) .
$$

If the acceleration is positive, negative, or zero, the rate of technical change is increasing, decreasing, or independent of the level of technology.

Similarly, we can define the difference of the difference in technology as the derivative of the difference in technology between Japan and United States with respect to the dummy variable. ${ }^{6}$

$$
\frac{\partial v_{D}^{i}}{\partial D}=\frac{\partial^{2} \ln Z_{i}}{\partial D^{2}}=\beta_{D D}^{i}, \quad(i=1,2, \ldots, l) .
$$


If this difference is positive, negative, or zero, the difference in technology is increasing, decreasing, or independent, respectively, of the dummy variable. For the translog production functions, both the accelerations $\left(\beta_{T T}^{i}\right)$ and the differences $\left(\beta_{D D}^{i}\right)$ are constant. This completes the detailed characterization of producer behavior in terms of the parameters of our bilateral translog models of production.

To estimate the unknown parameters of the bilateral translog production function we combine the first two equations for the average value shares in Japan and the United States, the equations for the average rates of technical change in the two countries, and the equation for the average difference in technology to obtain a complete econometric model of production. We estimate the parameters of the equations for the remaining average value shares in the two countries, using the restrictions on these parameters given below in appendix $\mathrm{A}$. The complete model involves 14 unknown parameters. A total of 16 additional parameters can be estimated as functions of these parameters, given the restrictions. Our estimates of the unknown parameters of the econometric model of production is based on the nonlinear three-stage least squares estimator introduced by Jorgenson and Laffont (1974).

\subsection{Empirical Results}

To implement the bilateral econometric models of production developed in section 2.2, we employ a data base for 28 U.S. and Japanese industrial sectors compiled by Jorgenson, Kuroda and Nishimizu (1987). For each sector they have assembled data on the value shares of capital, labor, and intermediate inputs for both countries, annually, for the period 1960-79. They have also compiled quantity indices of output and all three inputs for both countries for the same period. Finally, they have developed translog indexes of technical change for both countries and a translog index of the difference in technology between the two countries. There are 19 observations for each country, since two-period averages of all data are employed.

The parameters $\left(\alpha_{K}^{i}, \alpha_{L}^{i}, \alpha_{M}^{i}\right)$ can be interpreted as average value shares of capital input, labor input, and intermediate input, respectively, for the corresponding industrial sector in Japan and the United States. Similarly, the parameters $\left(\alpha_{T}^{i}\right)$ are averages of rates of technical change and the parameters $\left(\alpha_{D}^{i}\right)$ are averages of differences in technology between the two countries. The parameters $\left(\beta_{K K}^{i}, \beta_{K L}^{i}, \beta_{K M}^{i}, \beta_{L L}^{i}, \beta_{L M}^{i}, \beta_{M M}^{i}\right)$ can be interpreted as constant share elasticities with respect to quantity for the corresponding sector in Japan and the United States.

Similarly, the parameters $\left(\beta_{K T}^{i}, \beta_{L T}^{i}, \beta_{M T}^{i}\right)$ are constant biases of technical change with respect to quantity for the corresponding sector in the two countries, and the parameters $\left(\beta_{K D}^{i}, \beta_{L D}^{i}, \beta_{M D}^{i}\right)$ are constant biases of differences in technology between the two countries. Finally, the parameters $\left(\beta_{T T}^{i}\right)$ are con- 
stant accelerations of technical change in Japan and the United States, the parameters $\left(\boldsymbol{\beta}_{T D}^{i}\right)$ are constant biases of technical change with respect to the difference in technology between the two countries, and the parameters $\left(\beta_{D D}^{i}\right)$ are constant differences in the difference in technology.

In estimating the parameters of our bilateral models of production, we retain the average value shares, the average rate of technical change, and the average difference in technology between the two countries as parameters to be estimated for all 28 industrial sectors. Similarly, we estimate the biases of technical change, the biases of differences in technology, and the biases of technical change with respect to the difference in technology. Finally, we estimate the accelerations of technical change and the differences in the difference in technology for all 28 sectors.

Estimates of the share elasticities with respect to quantity are obtained under the restrictions implied by the necessary and sufficient conditions for concavity of the bilateral production function described in appendix A below. Under these restrictions the matrices of constant share elasticities must be nonpositive definite for all industries. To impose the concavity restrictions, we represent the matrices of constant share elasticities for all sectors in terms of their Cholesky factorizations. The necessary and sufficient conditions are that the diagonal elements $\left(\delta_{1}^{i}, \delta_{2}^{i}\right)$ of the matrices $\left(D^{i}\right)$ that appear in the Cholesky factorizations must be nonpositive. The estimates presented below in appendix B incorporate these restrictions for all 28 industries.

Our interpretation of the parameter estimates reported in appendix $B$ begins with an analysis of the estimates of the parameters $\left(\alpha_{K}^{i}, \alpha_{L}^{i}, \alpha_{M}^{i}, \alpha_{T}^{i}, \alpha_{D}^{i}\right)$. The average value shares are nonnegative for all 28 industries included in our study. The estimated average rates of technical change are positive in $19 \mathrm{sec}-$ tors and negative in 9 sectors. The estimated average differences in technology between the United States and Japan are positive in 17 sectors and negative in 11. For given input levels, differences in technology favor Japan in 17 of the 28 industries. The industries with positive and negative estimates of these parameters are listed in table 2.1.

The estimated share elasticities with respect to quantity $\left(\beta_{K K}^{i}, \beta_{K L}^{i}\right.$, $\left.\beta_{K M}^{i}, \beta_{L L}^{i}, \beta_{L M}^{i}, \beta_{M M}^{i}\right)$ describe the implications of patterns of substitution among capital, labor, and intermediate inputs for the relative distribution of the value of output among these three inputs. Positive share elasticities imply that the value shares increase with the quantity of the corresponding input; negative share elasticities imply that the value shares decrease with the input; share elasticities equal to zero imply that the value shares are independent of the input. It is important to keep in mind that we have fitted these parameters subject to the restrictions implied by concavity of the bilateral production functions. These restrictions require that all share elasticities be set equal to zero for six of the 28 industries-construction, food processing, stone, clay, and glass, machinery, transportation equipment, and precision instruments.

Our interpretation of the parameter estimates given in appendix B continues with the estimated elasticities of the share of each input with respect to the 


\begin{tabular}{|c|c|c|c|}
\hline \multicolumn{2}{|c|}{ Rates of Technical Change } & \multicolumn{2}{|c|}{ Differences in Technology } \\
\hline$\alpha_{r}>0$ & $\alpha_{r}<0$ & $\alpha_{D}>0$ & $\alpha_{D}<0$ \\
\hline (1) Agriculture, Forestry \& Fisheries & (2) Mining & (3) Construction & (1) Agriculture, Forestry \& Fisheries \\
\hline (4) Food \& Kindred Products & (3) Construction & (4) Food \& Kindred Products & (2) Mining \\
\hline (5) Textile Mill Products & (7) Lumber and Wood Products & (5) Textile Mill Products & (6) Apparel \& Other Fabricated \\
\hline (6) Apparel \& Other Fabricated Textile & (except furniture) & (7) Lumber \& Wood Products & Textiles \\
\hline Products & (12) Petroleum Refinery & (8) Furniture \& Fixtures & (9) Paper \& Allied Products \\
\hline (8) Furniture \& Fixtures & (15) Stone, Clay, \& Glass & (10) Printing \& Publishing & (12) Petroleum Refinery \\
\hline (9) Paper \& Allied Products & (16) Iron \& Steel & (11) Chemical \& Allied Products & (14) Leather \& Leather Products \\
\hline (10) Printing \& Publishing & (23) Miscellaneous Manufacturing & (13) Rubber \& Miscellaneous Plastic & (15) Stone, Clay \& Glass Products \\
\hline (11) Chemical & (25) Electric Utility, Gas Supply \& & Products & (16) Iron \& Steel \\
\hline (13) Rubber \& Miscellaneous Plastic & Water Supply & (17) Faabricated Metal & (18) Machinery \\
\hline (14) Leather & (28) Service & (20) Motor Vehicle \& Equipment & (19) Electric Machinery \\
\hline (17) Fabricated Metal Products & & (21) Transportation Equipment (except & (22) Precision Instruments \\
\hline (18) Machinery & & motor) & \\
\hline (19) Electric Machinery & & (23) Miscellaneous Manufacturing & \\
\hline (20) Motor Vehicles \& Equipment & & (24) Transportation \& Communication & \\
\hline (21) Transportation Equipment (except & & (25) Electrical Utilities, Gas Supply \& & \\
\hline motor) & & Water Supply & \\
\hline (22) Precision Instruments & & (26) Wholesale \& Retail Trade & \\
\hline (24) Transportation \& Communication & & (27) Finance \& Insurance & \\
\hline (26) Wholesale \& Retail Trade & & (28) Service & \\
\hline (27) Finance \& Insurance & & & \\
\hline
\end{tabular}


quantity of the input itself $\left(\beta_{K K}^{i}, \beta_{L L}^{i}, \beta_{M M}^{i}\right)$. Under the necessary and sufficient conditions for concavity of the bilateral production functions, these share elasticities are nonpositive. The share of each input is nonincreasing in the quantity of the input itself. This condition together with the condition that the sum of all the share elasticities with respect to a given input is equal to zero implies that only one of the elasticities of the share of each input with respect to the quantities of the other two inputs $\left(\beta_{K L}^{i}, \beta_{K M}^{i}, \beta_{L M}^{i}\right)$ can be negative. All three of these share elasticities can be nonnegative, and this condition holds for 17 of the 28 industries.

The share elasticity of capital with respect to the quantity of labor $\left(\beta_{K L}^{i}\right)$ is nonnegative for all 28 industries. By symmetry this parameter can also be interpreted as the share elasticity of labor with respect to the quantity of capital. This share elasticity is positive for the 15 industries listed in table 2.2 and zero for the remaining 13 industries. The share elasticity of capital with respect to the quantity of intermediate input $\left(\beta_{K M}^{i}\right)$ is negative for the five industries listed in table 2.2, zero for 13 industries and positive for 10 industries. This parameter can also be interpreted as the share elasticity of intermediate input with respect to the quantity of capital. Finally, the share elasticity of labor with respect to the quantity of intermediate input $\left(\beta_{L M}^{i}\right)$ is negative for the 6 industries listed in table 2.2, zero for 6 industries, and positive for 16 industries. This last parameter can also be interpreted as the share elasticity of intermediate input with respect to the quantity of labor.

We continue the interpretation of parameter estimates given in Appendix B with the estimated biases of technical change with respect to the quantity of each input $\left(\beta_{\mathrm{KT}}^{\mathrm{i}}, \beta_{L T}^{i}, \beta_{M T}^{i}\right)$. The estimated biases describe the implications of technical change for the relative distribution of the value of output among capital, labor, and intermediate inputs. Alternatively, they give the implications of patterns of substitution among these three inputs for the rate of technical change. Positive biases imply that the value shares increase with the level of technology; negative biases imply that the value shares decrease with technology. If a bias is positive, we say that technical change uses the corresponding input; if a bias is negative, we say that technical change saves the input. Input-using change implies that the rate of technical change increases with the quantity of the corresponding input, while input-saving change implies that this rate decreases with the input.

The sum of the three biases of technical change with respect to quantity is equal to zero, so that we can rule out the possibility that the three biases are either all negative or all positive. Of the six remaining logical possibilities, only capital-saving and intermediate input-saving and labor-using technical change fails to occur among the results for individual industries presented in table 2.3. The biases of technical change are not affected by the concavity restrictions on the bilateral production functions, so that all three parameters are fitted for each of the 28 industries included in our study.

We first consider the bias of technical change with respect to the quantity of capital input. If the estimated value of this parameter is positive, technical 
Table 2.2

Share Elasticities

\begin{tabular}{|c|c|c|c|c|c|c|c|c|}
\hline \multicolumn{3}{|c|}{ Capital-Labor } & \multicolumn{3}{|c|}{ Capital-Intermediate } & \multicolumn{3}{|c|}{ Labor-Intermediate } \\
\hline$\beta_{K L}<0$ & $\beta_{K L}=0$ & $\beta_{K L}>0$ & $\beta_{K M}<0$ & $\beta_{K M}=0$ & $\beta_{K M}>0$ & $\beta_{L M}<0$ & $\beta_{L M}=0$ & $\beta_{L M}>0$ \\
\hline$\ldots$ & $\begin{array}{l}\text { (3) Construction } \\
\text { (4) Foods } \\
\text { (5) Textiles } \\
\text { (11) Chernical } \\
\text { (14) Leather } \\
\text { (15) Stone, Clay } \\
\text { (16) Iron \& Steel } \\
\text { (18) Machinery } \\
\text { (21) Transportation } \\
\text { Equipment } \\
\text { (22) Precision } \\
\text { Instruments } \\
\text { (23) Miscellaneous } \\
\text { Manufacturing } \\
\text { (25) Utilities } \\
\text { (27) Finance }\end{array}$ & $\begin{array}{l}\text { (1) Agriculture } \\
\text { (2) Mining } \\
\text { (6) Apparel } \\
\text { (7) Lumber } \\
\text { (8) Furniture } \\
\text { (9) Paper } \\
\text { (10) Printing } \\
\text { (12) Petroleum } \\
\text { (13) Rubber } \\
\text { (17) Fabricated Metal } \\
\text { (19) Electric Machinery } \\
\text { (20) Motor Vehicles } \\
\text { (24) Transportation \& } \\
\text { Communication } \\
\text { (26) Trade } \\
\text { (30) Other Services }\end{array}$ & $\begin{array}{l}\text { (8) Furniture } \\
\text { (13) Rubber } \\
\text { (19) Electrical } \\
\text { Machinery } \\
\text { (24) Transportation \& } \\
\text { Communication } \\
\text { (30) Other Services }\end{array}$ & $\begin{array}{l}\text { (3) Construction } \\
\text { (4) Foods } \\
\text { (5) Textiles } \\
\text { (11) Chemical } \\
\text { (14) Leather } \\
\text { (15) Stone, Clay } \\
\text { (16) Iron \& Steel } \\
\text { (18) Machinery } \\
\text { (21) Transportation } \\
\text { Equipment } \\
\text { (22) Precision } \\
\text { Instruments } \\
\text { (23) Miscellaneous } \\
\text { Manufacturing } \\
\text { (25) Utilities } \\
\text { (27) Finance }\end{array}$ & $\begin{array}{l}\text { (1) Agriculture } \\
\text { (2) Mining } \\
\text { (6) Apparel } \\
\text { (7) Lumber } \\
\text { (9) Paper } \\
\text { (10) Printing } \\
\text { (12) Petroleum } \\
\text { (17) Fabricated Metal } \\
\text { (20) Motor Vehicle } \\
\text { (26) Trade }\end{array}$ & $\begin{array}{l}\text { (1) Agriculture } \\
\text { (2) Mining } \\
\text { (6) Apparel } \\
\text { (7) Lumber } \\
\text { (20) Motor Vehicle } \\
\text { (26) Trade }\end{array}$ & $\begin{array}{l}\text { (3) Construction } \\
\text { (4) Foods } \\
\text { (15) Stone, Clay } \\
\text { (18) Machinery } \\
\text { (21) Transportation } \\
\text { Equipment } \\
\text { (22) Precision } \\
\text { Instruments }\end{array}$ & $\begin{array}{l}\text { (5) Textile } \\
\text { (8) Furniture } \\
\text { (9) Paper } \\
\text { (10) Printing } \\
\text { (11) Chemical } \\
\text { (12) Petroleum } \\
\text { (13) Rubber } \\
\text { (14) Leather } \\
\text { (16) Iron \& Steel } \\
\text { (17) Fabricated Metal } \\
\text { (19) Electric Machinery } \\
\text { (23) Miscellaneous } \\
\quad \text { Manufacturing } \\
\text { (24) Transportation \& } \\
\quad \text { Communication } \\
\text { (25) Utilities } \\
\text { (27) Finance } \\
\text { (30) Other Services }\end{array}$ \\
\hline
\end{tabular}


Table 2.3

Biases of Technical Change

\begin{tabular}{ll}
\hline$\beta_{T K}>0$ & (3) Construction, (5) Textile, (26) Trade \\
$\beta_{T L}>0$ & $\cdots$ \\
$\beta_{T M}<0$ & (1) Agriculture, (8) Furniture, (10) Printing \\
$\beta_{T K}>0$ & (17) Fabricated Metal, (19) Electric Machinery, (21) Transportation Equipment \\
$\beta_{T L}<0$ & (24) Transportation \& Communication \\
$\beta_{T M}>0$ & (6) Apparel, (7) Lumber \\
$\beta_{T K}>0$ & $\cdots$ \\
$\beta_{T L}<0$ & $\ldots$ \\
$\beta_{T M}<0$ & $\cdots$ \\
$\beta_{T K}<0$ & (4) Foods, (9) Paper, (16) Iron \& Steel \\
$\beta_{T L}>0$ & (20) Motor Vehicles, (22) Precision Instruments, (27) Finance \\
$\beta_{T M}>0$ & (30) Other Services \\
$\beta_{T K}<0$ & $\cdots$ \\
$\beta_{T L}>0$ & $\cdots$ \\
$\beta_{T M}<0$ & $\cdots$ \\
$\beta_{T K}<0$ & (2) Mining, (11) Chemical, (12) Petroleum \\
$\beta_{T L}<0$ & (13) Rubber, (14) Leather, (15) Stone, Clay \\
$\beta_{T M}<0$ & (18) Machinery, (23) Miscellaneous Manufacturing, (25) Utilities
\end{tabular}

change is capital using. Alternatively, the rate of technical change increases with an increase in the quantity of capital input. If the estimated value is negative, technical change in capital saving and the rate of technical change decrease with the quantity of capital input. Technical change is capital using for 12 of the 28 industries included in our study and capital saving for the remaining 16.

The interpretation of biases of technical change with respect to the quantities of labor and intermediate inputs is analogous to the interpretation of the bias for capital input. Technical change is labor using for 10 of the 28 industries and laborsaving for the 18 remaining industries. Technical change is intermediate input using for 23 of the 28 industries and intermediate input saving for the remaining 5 . We conclude that technical change is predominantly capital saving, laborsaving, and intermediate input using for Japanese and U.S. industries.

We next consider the interpretation of the estimated biases of the difference in technology with respect to the quantity of each input $\left(\beta_{K D}^{i}, \beta_{L D}^{i}, \beta_{M D}^{i}\right)$. The estimated biases describe the implications of the difference in technology between the United States and Japan for the relative distribution of the value of output among capital, labor, and intermediate inputs. Alternatively, they give the implications of patterns of substitution among these three inputs for the difference in technology. Positive biases imply that the value shares increase from the United States and Japan; negative biases imply that the value shares decrease from the United States to Japan. If a bias is positive, we say that the difference in technology between the United States and Japan uses the corresponding input; if a bias is negative, we say that technical change saves the 
Table 2.4

Biases of the Differences in Technology

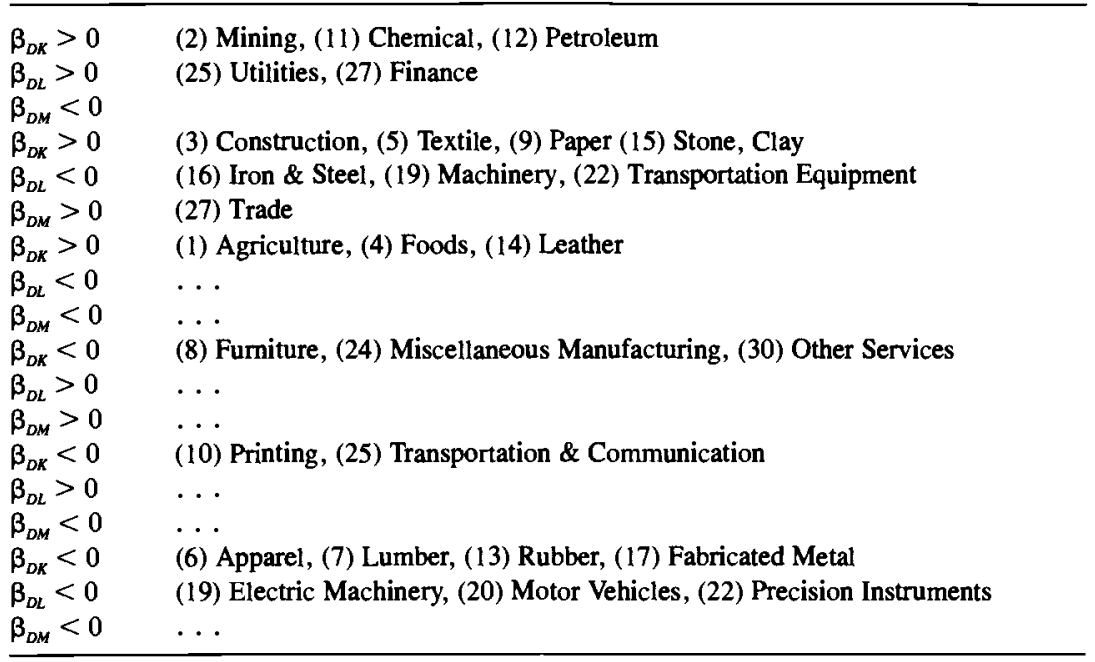

input. An input using difference in technology implies that the difference in technology increases with the quantity of the corresponding input, while input-saving change implies that this rate decreases with the input.

The sum of the three biases of the difference in technology with respect to quantity is equal to zero, so that we can rule out the possibility that the three biases are either all negative or all positive. All six of the remaining logical possibilities occur among the results for individual industries presented in table 2.4. The biases of the difference in technology, like the biases of technical change, are not affected by the concavity restrictions on the bilateral production functions, so that all three parameters are fitted for each of the 28 industries included in our study.

We first consider the bias of the difference in technology between the United States and Japan with respect to the quantity of capital input. If the estimated value of this parameter is positive, the difference in technology is capital using. Alternatively, the difference in technology increases with an increase in the quantity of capital input. If the estimated value is negative, the difference in technology is capital saving and the difference in technology decreases with the quantity of capital input. The difference in technology is capital using for 16 of the 28 industries included in our study and capital saving for the remaining 12 .

The interpretation of biases of the difference in technology with respect to the quantities of labor and intermediate inputs is analogous to the interpretation of the bias for capital input. The difference in technology between the United States and Japan is labor using for 10 of the 28 industries and laborsaving for the 18 remaining industries. The difference in technology is interme- 
diate input using for 18 of the 28 industries and intermediate input saving for the remaining 10 . We conclude that, for given input prices and a given level of technology, production is more capital intensive and intermediate input intensive in Japanese industries and more labor intensive in U.S. industries.

We continue with the interpretation of the estimated biases of technical change with respect to the difference in technology between the United States and Japan $\left(\beta_{T D}\right)$. The estimated biases describe the implications of the difference in technology for the rate of technical change. Alternatively, they give the implications of the level of technology for the difference in technology. A positive bias implies that the rate of technical change increases from the United States to Japan; a negative bias implies that the rate of technical change decreases from the United States to Japan. Alternatively, a positive bias implies that the difference in technology between the United States and Japan increases with the level of technology, while a negative bias implies that the difference in technology between the two countries decreases with the level. The rate of technical change increases from the United States to Japan for 22 of the 28 industries included in our study; the rate of technical change decreases for only six of the 28 industries. More detailed results are given in table 2.5 .

Our interpretation of the parameter estimates given in appendix B concludes with the accelerations of technical change $\left(\beta_{T T}^{i}\right)$ and the differences in the difference in technology $\left(\boldsymbol{\beta}_{D D}^{i}\right)$. A positive acceleration corresponds to a rate of technical change that is increasing with the level of technology, while a negative acceleration implies that the rate of technical change is decreasing with the level of technology. The estimated accelerations given in table 2.6 are positive for 10 industries and negative for the 18 remaining industries. A positive difference in the difference in technology corresponds to a difference in technology that is increasing between the United States and Japan, while a negative difference implies that the estimated differences given in table 2.6 are positive for 11 industries and negative for the 17 remaining industries.

\subsection{Conclusion}

Our empirical results on bilateral models of production in Japan and the United States reveal some striking differences between the two countries. With identical relative quantities of all inputs, Japanese industries have higher rates of compensation for capital and intermediate inputs than their U.S. counterparts. By contrast U.S. industries have higher rates of labor compensation than the corresponding Japanese industries. It is important to emphasize that these differences in technology would prevail under identical input proportions in the two countries. The observed patterns of production also reflect differences in these proportions.

High rates of technical change in Japan relative to the United States have been revealed by the results of Jorgenson, Kuroda, and Nishimizu (1987). Our finding that rates of technical change increase from the United States to Japan 


\section{Table 2.5}

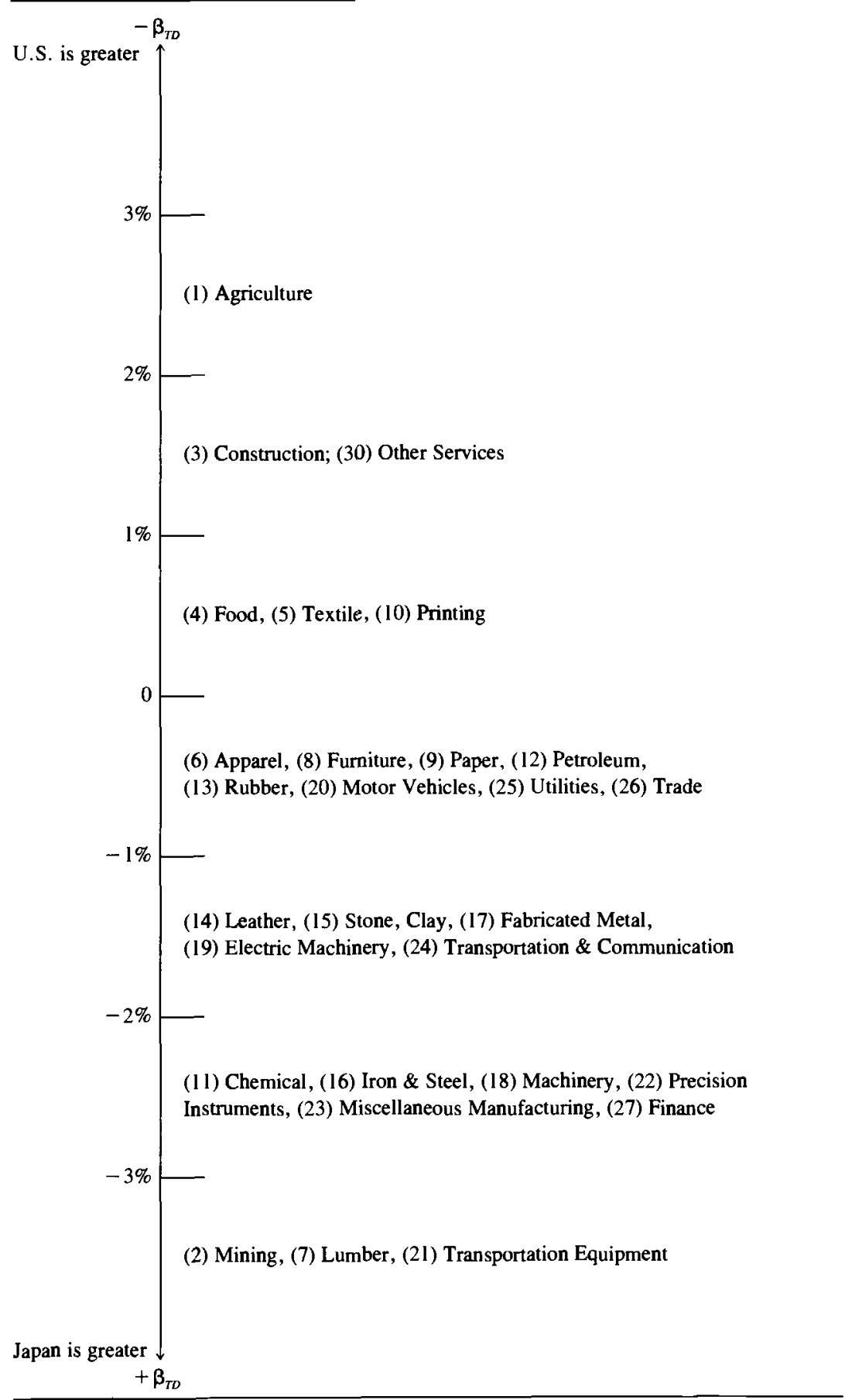




\begin{tabular}{|c|c|c|c|}
\hline \multicolumn{2}{|c|}{ Accelerations of Technical Change } & \multicolumn{2}{|c|}{ Differences in the Difference in Technology } \\
\hline$\beta_{T T}>0$ & $\beta_{T T}<0$ & $\beta_{D D}>0$ & $\beta_{D D}<0$ \\
\hline (1) Agriculture & (2) Mining & (I) Agriculture & (3) Construction \\
\hline (4) Food & (3) Construction & (2) Mining & (4) Food \\
\hline (6) Apparel & (5) Textile & (6) Apparel & (5) Textile \\
\hline (10) Printing & (7) Lumber & (9) Paper & (7) Lumber \\
\hline (13) Rubber & (8) Furniture & (12) Petroleum & (8) Furniture \\
\hline (16) Iron \& Steel & (9) Paper & (14) Leather & (10) Printing \\
\hline (18) Machinery & (11) Chemical & (15) Stone, Clay & (II) Chemical \\
\hline (19) Electric Machinery & (12) Petroleum & (16) Iron \& Steel & (13) Rubber \\
\hline (20) Motor Vehicles & (14) Leather & (18) Machinery & (17) Fabricated Metals \\
\hline \multirow[t]{9}{*}{ (27) Finance } & (15) Stone, Clay & (19) Electric Machinery & (20) Motor Vehicles \\
\hline & (17) Fabricated Metal & (22) Precision & (21) Transportation Equipment \\
\hline & (21) Transportation Equipment & Instruments & (23) Miscellaneous Manufacturing \\
\hline & (22) Precision Instruments & & (24) Transportation \& Communication \\
\hline & (23) Miscellaneous Manufacturing & & (25) Electric Utilities \\
\hline & (24) Transportation \& Communication & & (26) Wholesale \& Retail Trade \\
\hline & (25) Electric Utilities, Gas Supply \& Water Supply & & (27) Finance \\
\hline & (26) Wholesale \& Retail Trade & & (28) Service \\
\hline & (28) Service & & \\
\hline
\end{tabular}


is, therefore, not surprising. This increase characterizes 22 of the 28 industries included in our study. An alternative and equivalent interpretation of these results is that the difference in technology between the United States and Japan increases with the level of technology. The technology gap between the two countries is closing for most industries at given relative quantities of all inputs. Observed changes in the technology gaps also reflect changes in input proportions.

Our bilateral models of production are based on strong simplifying assumptions. Although we allow for differences in the value shares of the three inputs-capital, labor, and intermediate inputs - the rate of technical change, and the difference in technology between the two countries, we require that share elasticities and the biases and accelerations of technical change are the same for each industry in the two countries. In addition, we have employed conditions for producer equilibrium under perfect competition, and we have assumed constant returns to scale at the industry level for both countries. These assumptions must be justified primarily by their usefulness in implementing production models that are uniform for all 28 industrial sectors in Japan and the United States.

Our important simplification of the theory of production is the imposition of concavity of the sectoral production function for Japan and the United States. By imposing concavity we have reduced the number of share elasticities to be fitted from 168, or six for each of our 28 industrial sectors, to 93 , or somewhat more than three per sector on average. All share elasticities are constrained to be zero for six of the 28 industries. The concavity constraints have contributed to the precision of our estimates but require that the share of each input be nonincreasing in the quantity of the input itself.

\section{Appendix A}

Our objective is to describe restrictions on the parameters of our econometric models. If a system of equations, consisting of value shares, the rate of technical change, and the difference in technology can be generated from a production function, we say that the system is integrable. A complete set of conditions for integrability is given below.

1. Homogeneity. The value shares, rate of technical change, and difference in technology are homogeneous of degree zero in the inputs.

We can write the value shares, the rate of technical change, and the difference in technology in the form

$$
\begin{gathered}
v^{i}=\alpha_{X}^{i}+B_{X X}^{i} \ln X_{i}+\beta_{X T}^{i} \cdot T+\beta_{X D}^{i} \cdot D, \\
v_{T}^{i}=\alpha_{T}^{i}+\beta_{X T}^{i} \ln X_{i}+\beta_{T T}^{i} \cdot T+\beta_{T D}^{i} \cdot D, \\
v_{D}^{i}=\alpha_{D}^{i}+\beta_{X D}^{i} \ln X_{i}+\beta_{T D}^{i}+T+\beta_{D D}^{i} \cdot D, \\
(i=1,2, \ldots, I) .
\end{gathered}
$$


where the parameters $\left(\alpha_{X}^{i}, \alpha_{T}^{i}, \alpha_{D}^{i}, B_{X X}^{i}, \beta_{X T}^{i}, \beta_{X D}^{i}, \beta_{T T}^{i}, \beta_{T D}^{i}, \beta_{D D}^{i}\right)$ are constant. Homogeneity implies that these parameters must satisfy

$$
\begin{aligned}
& \mathrm{B}_{X X}{ }^{i} i=0, \\
& \beta_{X T}^{i}{ }^{\prime} i=0, \\
& \beta_{X D}^{i}{ }^{\prime} i=0, \quad(i=1,2, \ldots, I),
\end{aligned}
$$

where $i$ is a vector of ones. Five restrictions are implied by homogeneity for three inputs.

2. Product exhaustion. The sum of the value shares is equal to unity:

$$
v_{i}^{\prime} i=1, \quad(i=1,2, \ldots, I) .
$$

The three inputs exhaust the value of the product. This implies that the parameters must satisfy the restrictions

$$
\begin{aligned}
& \alpha_{X}^{i} i=1, \\
& \mathrm{~B}_{X X}^{i}{ }^{\prime} i=0, \\
& \beta_{X T}^{i}{ }^{\prime} i=0, \\
& \beta_{X D}^{i}{ }^{\prime} i=0, \quad(i=1,2, \ldots, I) .
\end{aligned}
$$

Six restrictions are implied by product exhaustion for three inputs.

3. Symmetry. The matrix of share elasticities, biases, acceleration, and the difference in the difference in technology must be symmetric.

Imposing homogeneity and product exhaustion restrictions, we can represent the system of value shares, the rate of technical change, and the difference in technology without imposing symmetry. A necessary and sufficient condition for symmetry is that the matrix of parameters must satisfy the restrictions:

$$
\left[\begin{array}{lll}
\beta_{X X}^{i} & \beta_{X T}^{i} & \beta_{X D}^{i} \\
\beta_{X T}^{i} & \beta_{T T}^{i} & \beta_{T D}^{i} \\
\beta_{X D}^{i} & \beta_{T D}^{i} & \beta_{D D}^{i}
\end{array}\right]=\left[\begin{array}{lll}
\beta_{X X}^{i} & \beta_{X T}^{i} & \beta_{X D}^{i} \\
\beta_{X T}^{i} & \beta_{T T}^{i} & \beta_{T D}^{i} \\
\beta_{X D}^{i} & \beta_{T D}^{i} & \beta_{D D}^{i}
\end{array}\right]
$$

For three inputs the number of symmetry restrictions is 10 .

4. Nonnegativity. The value shares must be nonnegative.

$$
v_{i} \geqq 0, \quad(i=1,2, \ldots, I) .
$$

By product exhaustion the value shares sum to unity, so that we can write

$$
v_{i} \geq 0, \quad(i=1,2, \ldots, I),
$$

where $v_{i} \geq 0$ implies $v_{i} \geqq 0$ and $v_{i} \neq 0$.

Nonnegativity of the value shares is implied by monotonicity of the production functions. 


$$
\frac{\partial \ln Z_{i}}{\partial \ln X_{i}} \geqq 0, \quad(i=1,2, \ldots, I)
$$

For the translog production functions, the conditions for monotonicity take the form

$$
\frac{\partial \ln Z_{i}}{\partial \ln X_{i}}=\alpha_{x}^{i}+B_{X X}^{i} \ln X_{i}+\beta_{X T}^{i} \cdot T+\beta_{X D}^{i} \cdot D,(i=1,2, \ldots, I) .
$$

Since the production functions are quadratic in the logarithms of inputs $\ln X_{i}(i$ $=1,2, \ldots, l$ ), we can always choose inputs so that monotonicity is violated. Accordingly, there are no restrictions on the parameters that would imply nonnegativity of the value shares for all inputs. Instead we consider restrictions that imply concavity of the production functions for all nonnegative value shares.

5. Monotonicity. The matrix of share elasticities must be nonpositive definite.

Concavity of the production functions implies that Hessian matrices, say $\left(H_{i}\right)$, are nonpositive definite, so that the matrices $\left(\mathrm{B}_{x X}^{i}+v_{i} v_{i}^{\prime}-V_{i}\right)$ are nonpositive definite:

$$
\frac{1}{Z_{i}} \cdot N_{i} \cdot H_{i} \cdot N_{i}=\mathrm{B}_{X X}^{i}+v_{i} v_{i}^{\prime}-V_{i}, \quad(i=1,2, \ldots, l),
$$

where

$$
N_{i}=\left[\begin{array}{lll}
K_{i} & 0 & 0 \\
0 & L_{i} & 0 \\
0 & 0 & M_{i}
\end{array}\right], V_{i}=\left[\begin{array}{lll}
v_{k}^{i} & 0 & 0 \\
0 & v_{L}^{i} & 0 \\
0 & 0 & v_{M}^{i}
\end{array}\right], \quad(i=1,2, \ldots, I),
$$

the production functions are positive, so that $Z_{i}>0,(i=1,2, \ldots, I)$, and $\left(B_{x X}^{i}\right)$ are matrices of constant share elasticities defined above.

Without violating the product exhaustion and nonnegativity restrictions we can set the matrices $\left(v_{i} v_{i}^{\prime}-V_{i}\right)$ equal to zero, for example, by choosing one of the value shares equal to unity and the others equal to zero. Necessary conditions for the matrices $\left(\mathrm{B}_{x X}^{i}+v_{i} v_{i}^{\prime}-V_{i}\right)$ to be nonpositive definite are that the matrices of constant share elasticities $\left(\mathrm{B}_{X X}^{i}\right)$ must be nonpositive definite. These conditions are also sufficient, since the matrices $\left(v_{i} v_{i}{ }^{\prime}-V_{i}\right)$ are nonpositive definite for all nonnegative value shares summing to unity. The sum of two nonpositive definite matrices is nonpositive definite. ${ }^{7}$

To impose concavity on the translog production functions, the matrices of constant share elasticities $\left(\mathrm{B}_{X X}^{i}\right)$ can be represented in terms of the Cholesky factorizations: 


$$
\mathrm{B}_{X X}^{i}=T_{i} D_{i} T_{i}^{\prime}, \quad(i=1,2, \ldots, l),
$$

where the matrices $\left(T_{i}\right)$ are unit lower triangular and the matrices $\left(D_{i}\right)$ are diagonal. For three inputs we can write the matrices $\left(B_{x X}^{i}\right)$ in terms of their Cholesky factorizations as follows:

$$
\mathrm{B}=\left[\begin{array}{lll}
\delta_{l}^{i} & \lambda_{21}^{i} \delta_{l}^{i} & \lambda_{31}^{i} \delta_{l}^{i} \\
\lambda_{21} \delta_{l}^{i} & \lambda_{21}^{i} \lambda_{21}^{i} \delta_{l}^{i}+\delta_{2}^{i} & \lambda_{21}^{i} \lambda_{31}^{i} \delta_{l}^{i}+\lambda_{32}^{i} \delta_{2}^{i} \\
\lambda_{31}^{i} \delta_{l}^{i} & \lambda_{31}^{i} \lambda_{21}^{i} \delta_{l}^{i}+\lambda_{32}^{i} \delta_{2}^{i} & \lambda_{31}^{i} \lambda_{31}^{i} \delta_{l}^{i}+\lambda_{32}^{i} \lambda_{32}^{i} \delta_{2}^{i}+\delta_{3}^{i}
\end{array}\right],
$$

where

$$
T_{i}=\left[\begin{array}{lll}
l & 0 & 0 \\
\lambda_{21}^{i} & l & 0 \\
\lambda_{31}^{i} & \lambda_{32}^{i} & l
\end{array}\right], D_{i}=\left[\begin{array}{lll}
\delta_{l}^{i} & 0 & 0 \\
0 & \delta_{2}^{i} & 0 \\
0 & 0 & \delta_{3}^{i}
\end{array}\right], \quad(i=1,2, \ldots, I) .
$$

The matrices of constant share elasticities $\left(B_{x x}^{i}\right)$ must satisfy symmetry restrictions and restrictions implied by product exhaustion. These imply that the parameters of the Cholesky factorizations must satisfy the conditions:

$$
\begin{aligned}
1+\lambda_{2 l}^{i}+\lambda_{31}^{i} & =0, \\
1+\lambda_{32}^{i} & =0, \\
\delta_{3}^{i} & =0, \quad(i=1,2, \ldots, I) .
\end{aligned}
$$

Under these conditions there is a one-to-one transformation between the share elasticities $\left(\mathrm{B}_{x X}^{i}\right)$ and the parameters of the Cholesky factorizations $\left(T_{i}, D_{i}\right)$. The matrices of share elasticities are nonpositive definite if and only if the diagonal elements of the matrices $\left(D_{i}\right)$, the so-called Cholesky values, are nonpositive.

Our econometric models are generated from translog production functions for each industrial sector. To complete these models we add a stochastic component to the system of equations. We associate this component with unobservable random disturbances. Producers maximize profits for given prices of inputs, but the value shares, the rates of technical change, and the difference in technology are subject to random disturbances. These disturbances result from errors in implementation of production plans, random elements in technologies not reflected in the production functions, or errors of measurement. We assume that each equation has two additive components. The first is a nonrandom function of the inputs, time, and the dummy variable; the second is a random disturbance that is functionally independent of these variables. ${ }^{8}$ 


\section{Appendix B}

(Table 2B.1 follows on pages 78-81.) 


\begin{tabular}{|c|c|c|c|c|c|c|c|c|c|c|c|c|c|c|}
\hline \multirow[b]{2}{*}{ Parameter } & \multicolumn{14}{|c|}{ Industry } \\
\hline & $\begin{array}{l}\text { Agniculture. } \\
\text { Forestry \& } \\
\text { Fisheries }\end{array}$ & Mining & Construation & $\begin{array}{l}\text { Food \& } \\
\text { Kindred } \\
\text { Products }\end{array}$ & $\begin{array}{l}\text { Textile } \\
\text { Mill } \\
\text { Products }\end{array}$ & $\begin{array}{c}\text { Apparel \& } \\
\text { Other Fabricated } \\
\text { Texile Products }\end{array}$ & $\begin{array}{l}\text { Lumber \& } \\
\text { Wood Products. } \\
\text { Except Furniture }\end{array}$ & $\begin{array}{l}\text { Furniture } \\
\& \\
\text { Fixtures }\end{array}$ & $\begin{array}{l}\text { Paper \& } \\
\text { Allied } \\
\text { Products }\end{array}$ & $\begin{array}{l}\text { Printing. } \\
\text { Publishing \& } \\
\text { Allied Products }\end{array}$ & $\begin{array}{l}\text { Chemical \& } \\
\text { Allied } \\
\text { Products }\end{array}$ & $\begin{array}{c}\text { Petrolicum } \\
\text { Refinery \& } \\
\text { Related Induscries }\end{array}$ & $\begin{array}{c}\text { Rubber \& } \\
\text { Miscellaneous } \\
\text { Plastic Products }\end{array}$ & $\begin{array}{l}\text { Leather \& } \\
\text { Leather } \\
\text { Products }\end{array}$ \\
\hline$\alpha_{K}$ & $\begin{array}{r}.124 \\
(16.503)\end{array}$ & $\begin{array}{r}.281 \\
(36.681)\end{array}$ & $\begin{array}{r}.064 \\
(38.959)\end{array}$ & $\begin{array}{r}.065 \\
(26.212)\end{array}$ & $\begin{array}{r}.085 \\
(37.141)\end{array}$ & $\begin{array}{r}.040 \\
(15.397)\end{array}$ & $\begin{array}{r}.145 \\
(44.960)\end{array}$ & $\begin{array}{r}.065 \\
(33.621)\end{array}$ & $\begin{array}{r}.129 \\
(80.912)\end{array}$ & $\begin{array}{r}.109 \\
(52.086)\end{array}$ & $\begin{array}{r}.159 \\
(87.053)\end{array}$ & $\begin{array}{r}.091 \\
(16.958)\end{array}$ & $\begin{array}{r}.982 \\
(34.947)\end{array}$ & $\begin{array}{r}.054 \\
(21.223)\end{array}$ \\
\hline $\boldsymbol{\alpha}_{L}$ & $\begin{array}{r}.296 \\
(40.709)\end{array}$ & $\begin{array}{r}.184 \\
(79.135)\end{array}$ & $\begin{array}{r}.391 \\
(99.969)\end{array}$ & $\begin{array}{r}.164 \\
(54.226)\end{array}$ & $\begin{array}{r}.268 \\
(72.509)\end{array}$ & $\begin{array}{r}.326 \\
(105.669)\end{array}$ & $\begin{array}{r}.341 \\
(49.424)\end{array}$ & $\begin{array}{r}.356 \\
(49.171)\end{array}$ & $\begin{array}{r}.255 \\
(52.148)\end{array}$ & $\begin{array}{r}.394 \\
(96.059)\end{array}$ & $\begin{array}{r}.202 \\
(50.691)\end{array}$ & $\begin{array}{r}.103 \\
(22.254)\end{array}$ & $\begin{array}{r}.370 \\
(59.380)\end{array}$ & $\begin{array}{r}.356 \\
(69.442)\end{array}$ \\
\hline$\alpha_{M}$ & $\begin{array}{r}.580 \\
(119.647)\end{array}$ & $\begin{array}{r}.535 \\
(84.111)\end{array}$ & $\begin{array}{r}.545 \\
(164.769)\end{array}$ & $\begin{array}{r}.771 \\
(442.898)\end{array}$ & $\begin{array}{r}.646 \\
(133.167)\end{array}$ & $\begin{array}{r}.634 \\
(192.393)\end{array}$ & $\begin{array}{r}.514 \\
(71.545)\end{array}$ & $\begin{array}{r}.578 \\
(73.132)\end{array}$ & $\begin{array}{r}.616 \\
(109.489)\end{array}$ & $\begin{array}{r}.497 \\
(96.991)\end{array}$ & $\begin{array}{r}.639 \\
(141.025)\end{array}$ & $\begin{array}{r}.805 \\
(158.978)\end{array}$ & $\begin{array}{r}.532 \\
(75.830)\end{array}$ & $\begin{array}{r}.590 \\
(92.986)\end{array}$ \\
\hline$\alpha_{D}$ & $\begin{array}{r}-3940.953 \\
(-0.644)\end{array}$ & $\begin{array}{r}-40714.641 \\
(-1.588)\end{array}$ & $\begin{array}{r}9865.922 \\
(1.620)\end{array}$ & $\begin{array}{r}1218.600 \\
(.125)\end{array}$ & $\begin{array}{r}10900.395 \\
(.699)\end{array}$ & $\begin{array}{r}-17440.969 \\
(-1.923)\end{array}$ & $\begin{array}{r}7526.488 \\
(.802)\end{array}$ & $\begin{array}{r}26555.227 \\
(3.487)\end{array}$ & $\begin{array}{r}-1779.908 \\
(-.405)\end{array}$ & $\begin{array}{r}9356.211 \\
(.611)\end{array}$ & $\begin{array}{r}1655.133 \\
(.406)\end{array}$ & $\begin{array}{r}-35802.32 \\
(-1.633)\end{array}$ & $\begin{array}{r}2931.092 \\
(.178)\end{array}$ & $\begin{array}{r}-9925.094 \\
(-1.704)\end{array}$ \\
\hline$\alpha_{T}$ & $\begin{array}{r}.017 \\
(1.868)\end{array}$ & $\begin{array}{r}-.023 \\
(-.649)\end{array}$ & $\begin{array}{r}-.007 \\
(-0.992)\end{array}$ & $\begin{array}{r}.001 \\
(.037)\end{array}$ & $\begin{array}{r}.027 \\
(1.228)\end{array}$ & $\begin{array}{r}.010 \\
(1.316)\end{array}$ & $\begin{array}{r}-.012 \\
(-.566)\end{array}$ & $\begin{array}{r}.004 \\
(.496)\end{array}$ & $\begin{array}{r}.001 \\
(.033)\end{array}$ & $\begin{array}{r}.006 \\
(.362)\end{array}$ & $\begin{array}{r}.004 \\
(.455)\end{array}$ & $\begin{array}{r}-.044 \\
(-1.109)\end{array}$ & $\begin{array}{r}.014 \\
(.416)\end{array}$ & $\begin{array}{r}.004 \\
(.145)\end{array}$ \\
\hline$\beta_{K K}$ & . & $\ldots$ & $\cdots$ & $\ldots$ & . & $\begin{array}{r}-.102 \\
(-11.373)\end{array}$ & . & $\begin{array}{r}-.073 \\
(-6.001)\end{array}$ & $\begin{array}{r}-.010 \\
(-1.639)\end{array}$ & $\begin{array}{r}-.165 \\
(-7.715)\end{array}$ & . & . & $\begin{array}{r}-.016 \\
(-2.169)\end{array}$ & $\begin{array}{r}-.004 \\
(-.988)\end{array}$ \\
\hline$\beta_{L L}$ & & & & . & $\begin{array}{r}-.004 \\
(-.253)\end{array}$ & $\begin{array}{r}-.018 \\
(-2.745)\end{array}$ & . & $\begin{array}{r}-.111 \\
(-5.107)\end{array}$ & $\begin{array}{r}-.0563 \\
(-2.890)\end{array}$ & $\begin{array}{r}-.182 \\
(-8.618)\end{array}$ & $\begin{array}{r}-.124 \\
(-17.996)\end{array}$ & $\ldots$ & $\begin{array}{r}-.115 \\
(-5.818)\end{array}$ & $\begin{array}{r}-.092 \\
(-3.517)\end{array}$ \\
\hline$\beta_{M M}$ & $\cdots$ & $\cdots$ & $\ldots$ & . & $\begin{array}{r}-.004 \\
(-.253)\end{array}$ & $\begin{array}{r}-.034 \\
(-3.490)\end{array}$ & $\ldots$ & $\begin{array}{r}-.004 \\
(-.855)\end{array}$ & $\begin{array}{r}-.027 \\
(-1.033)\end{array}$ & $\begin{array}{r}-.053 \\
(-2.508)\end{array}$ & $\begin{array}{r}-.124 \\
(-17.996)\end{array}$ & $\ldots$ & $\begin{array}{r}-.045 \\
(-3.509)\end{array}$ & $\begin{array}{r}-.056 \\
(-1.914)\end{array}$ \\
\hline$\beta_{D D}$ & $\begin{array}{r}7881.535 \\
(.644)\end{array}$ & $\begin{array}{r}81429.375 \\
(1.588)\end{array}$ & $\begin{array}{r}-19732.504 \\
(-1.620)\end{array}$ & $\begin{array}{r}-2437.716 \\
(-0.125)\end{array}$ & $\begin{array}{r}-21801.141 \\
(-.699\end{array}$ & $\begin{array}{r}34881.598 \\
(1.923)\end{array}$ & $\begin{array}{r}-15053.172 \\
(-.802)\end{array}$ & $\begin{array}{r}-53111.727 \\
(-3.487)\end{array}$ & $\begin{array}{r}3559.253 \\
(.404)\end{array}$ & $\begin{array}{r}-18714.41 \\
(-.611)\end{array}$ & $\begin{array}{r}-3309.924 \\
(-.406)\end{array}$ & $\begin{array}{r}71604.250 \\
(1.633)\end{array}$ & $\begin{array}{r}-5862.695 \\
(-.178)\end{array}$ & $\begin{array}{r}19849.809 \\
(1.704)\end{array}$ \\
\hline
\end{tabular}




\begin{tabular}{|c|c|c|c|c|c|c|c|c|c|c|c|c|c|c|}
\hline$\beta_{T T}$ & $\begin{array}{r}.001 \\
(.729)\end{array}$ & $\begin{array}{r}-.003 \\
(-.464)\end{array}$ & $\begin{array}{r}-.001 \\
(-1.031)\end{array}$ & $\begin{array}{r}.001 \\
(.272)\end{array}$ & $\begin{array}{r}-.001 \\
(-.347)\end{array}$ & $\begin{array}{l}.0002 \\
(.181)\end{array}$ & $\begin{array}{r}-.006 \\
(-1.615)\end{array}$ & $\begin{array}{r}-.002 \\
(-1.368)\end{array}$ & $\begin{array}{r}-.002 \\
(-.738)\end{array}$ & $\begin{array}{r}.0002 \\
(.091)\end{array}$ & $\begin{array}{r}-.301 \\
(-1.827)\end{array}$ & $\begin{array}{r}-.003 \\
(-.450)\end{array}$ & $\begin{array}{r}.001 \\
(.128)\end{array}$ & $\begin{array}{r}-.003 \\
(-.569)\end{array}$ \\
\hline$\beta_{L X}$ & $\ldots$ & . & $\ldots$ & $\ldots$ & 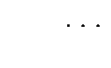 & $\begin{array}{r}.043 \\
(5.159)\end{array}$ & & $\begin{array}{r}.901 \\
(7.377)\end{array}$ & $\begin{array}{r}.020 \\
(2.010)\end{array}$ & $\begin{array}{r}.147 \\
(11.620)\end{array}$ & $\ldots$ & . & $\begin{array}{r}.043 \\
(3.561)\end{array}$ & $\begin{array}{r}.020 \\
(2.065)\end{array}$ \\
\hline$\beta_{M K}$ & . & $\ldots$ & . & $\ldots$ & . & $\begin{array}{r}.059 \\
(6.045)\end{array}$ & $\ldots$ & $\begin{array}{r}-.017 \\
(-1.826)\end{array}$ & $\begin{array}{r}-.010 \\
(-.913)\end{array}$ & $\begin{array}{r}.018 \\
(.973)\end{array}$ & $\ldots$ & $\ldots$ & $\begin{array}{r}-.027 \\
(-5.047)\end{array}$ & $\begin{array}{r}-.016 \\
(-2.803)\end{array}$ \\
\hline$\beta_{M L}$ & $\cdots$ & $\ldots$ & $\ldots$ & . & $\begin{array}{r}.004 \\
(.253)\end{array}$ & $\begin{array}{r}-.025 \\
(-10.367)\end{array}$ & & $\begin{array}{r}.021 \\
(1.502)\end{array}$ & $\begin{array}{r}.036 \\
(1.814)\end{array}$ & $\begin{array}{r}.034 \\
(1.994)\end{array}$ & $\begin{array}{r}.124 \\
(17.996)\end{array}$ & 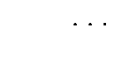 & $\begin{array}{r}.072 \\
(4.979)\end{array}$ & $\begin{array}{r}.072 \\
(2.565)\end{array}$ \\
\hline$\beta_{D K}$ & $\begin{array}{r}.216 \\
(24.660)\end{array}$ & $\begin{array}{r}.060 \\
(3.458)\end{array}$ & $\begin{array}{r}.070 \\
(11.021)\end{array}$ & $\begin{array}{r}.176 \\
(18.730)\end{array}$ & $\begin{array}{r}.106 \\
(41.254)\end{array}$ & $\begin{array}{r}.003 \\
(.215)\end{array}$ & $\begin{array}{r}-.077 \\
(-12.093)\end{array}$ & $\begin{array}{r}-.144 \\
(-7.172)\end{array}$ & $\begin{array}{r}-.006 \\
(-.388)\end{array}$ & $\begin{array}{r}-.234 \\
(-11.604)\end{array}$ & $\begin{array}{r}.012 \\
(1.414)\end{array}$ & $\begin{array}{r}.111 \\
(6.796)\end{array}$ & $\begin{array}{r}-.022 \\
(-1.442)\end{array}$ & $\begin{array}{r}.003 \\
(.189)\end{array}$ \\
\hline$\beta_{D L}$ & $\begin{array}{r}-.035 \\
(-4.223)\end{array}$ & $\begin{array}{r}.080 \\
(10.218)\end{array}$ & $\begin{array}{r}-.165 \\
(-24.873)\end{array}$ & $\begin{array}{r}-.057 \\
(-8.670)\end{array}$ & $\begin{array}{r}-.168 \\
(-6.149)\end{array}$ & $\begin{array}{r}-.104 \\
(-9.498)\end{array}$ & $\begin{array}{r}-.155 \\
(-11.236)\end{array}$ & $\begin{array}{r}.098 \\
(2.493)\end{array}$ & $\begin{array}{r}-.060 \\
(-1.859)\end{array}$ & $\begin{array}{r}.216 \\
(6.104)\end{array}$ & $\begin{array}{r}.048 \\
(5.017)\end{array}$ & $\begin{array}{r}-.068 \\
(-12.542)\end{array}$ & $\begin{array}{r}-.025 \\
(-1.056)\end{array}$ & $\begin{array}{r}-.071 \\
(-2.180)\end{array}$ \\
\hline$\beta_{D M}$ & $\begin{array}{r}-.181 \\
(-39.107)\end{array}$ & $\begin{array}{r}-.139 \\
(-10.382)\end{array}$ & $\begin{array}{r}.095 \\
(22.882)\end{array}$ & $\begin{array}{r}-.119 \\
(-14.538)\end{array}$ & $\begin{array}{r}.062 \\
(2.241)\end{array}$ & $\begin{array}{r}.101 \\
(16.295)\end{array}$ & $\begin{array}{r}.233 \\
(20.756)\end{array}$ & $\begin{array}{r}.046 \\
(1.678)\end{array}$ & $\begin{array}{r}.066 \\
(1.911)\end{array}$ & $\begin{array}{r}.018 \\
(.601)\end{array}$ & $\begin{array}{r}-.060 \\
(-6.175)\end{array}$ & $\begin{array}{r}-.042 \\
(-2.894)\end{array}$ & $\begin{array}{r}.047 \\
(3.063)\end{array}$ & $\begin{array}{r}.068 \\
(1.964)\end{array}$ \\
\hline$\beta_{T K}$ & $\begin{array}{r}.003 \\
(3.393)\end{array}$ & $\begin{array}{r}-.001 \\
(-1.518)\end{array}$ & $\begin{array}{r}.001 \\
(4.059)\end{array}$ & $\begin{array}{r}-.002 \\
(-6.429)\end{array}$ & $\begin{array}{r}.001 \\
(3.236)\end{array}$ & $\begin{array}{r}.004 \\
(9.256)\end{array}$ & $\begin{array}{r}.0007 \\
(1.781)\end{array}$ & $\begin{array}{r}.002 \\
(3.50)\end{array}$ & $\begin{array}{l}.0002 \\
(.621)\end{array}$ & $\begin{array}{r}.003 \\
(7.843)\end{array}$ & $\begin{array}{r}-.004 \\
(-12.956)\end{array}$ & $\begin{array}{r}-.004 \\
(-6.831)\end{array}$ & $\begin{array}{l}-.0003 \\
(-.602)\end{array}$ & $\begin{array}{r}.001 \\
(1.470)\end{array}$ \\
\hline$\beta_{T L}$ & $\begin{array}{r}-.004 \\
(-6.082)\end{array}$ & $\begin{array}{r}-.003 \\
(-9.162)\end{array}$ & $\begin{array}{r}.003 \\
(11.479)\end{array}$ & $\begin{array}{r}-.0002 \\
(-1.373)\end{array}$ & $\begin{array}{r}.001 \\
(1.160)\end{array}$ & $\begin{array}{l}.0002 \\
(.410\end{array}$ & $\begin{array}{r}-.003 \\
(-7.560)\end{array}$ & $\begin{array}{r}-.005 \\
(-4.068)\end{array}$ & $\begin{array}{r}-.002 \\
(-1.694)\end{array}$ & $\begin{array}{r}-.004 \\
(-6.568)\end{array}$ & $\begin{array}{r}-.006 \\
(-11.492)\end{array}$ & $\begin{array}{r}-.001 \\
(-8.951)\end{array}$ & $\begin{array}{r}-.001 \\
(-.700)\end{array}$ & $\begin{array}{r}-.002 \\
(-1.608)\end{array}$ \\
\hline$\beta_{T M}$ & $\begin{array}{r}.001 \\
-4.064)\end{array}$ & $\begin{array}{r}.004 \\
(11.288)\end{array}$ & $\begin{array}{r}-.004 \\
(-13.935)\end{array}$ & $\begin{array}{r}.002 \\
(11.688)\end{array}$ & $\begin{array}{r}-.002 \\
(-2.258)\end{array}$ & $\begin{array}{r}-.005 \\
(-7.021)\end{array}$ & $\begin{array}{r}.002 \\
(6.928)\end{array}$ & $\begin{array}{r}.003 \\
(2.809)\end{array}$ & $\begin{array}{r}.002 \\
(1.506)\end{array}$ & $\begin{array}{r}.001 \\
(.985)\end{array}$ & $\begin{array}{r}.010 \\
(16.974)\end{array}$ & $\begin{array}{r}.005 \\
(9.426)\end{array}$ & $\begin{array}{r}.001 \\
(1.065)\end{array}$ & $\begin{array}{r}.001 \\
(.890)\end{array}$ \\
\hline$\beta_{T D}$ & $\begin{array}{r}-.023 \\
(-11.723)\end{array}$ & $\begin{array}{r}.060 \\
(8.201)\end{array}$ & $\begin{array}{r}-.012 \\
(-4.577)\end{array}$ & $\begin{array}{l}.0002 \\
(.088)\end{array}$ & $\begin{array}{r}-.015 \\
(-3.172)\end{array}$ & $\begin{array}{r}.006 \\
(2.127)\end{array}$ & $\begin{array}{r}.033 \\
(12.214)\end{array}$ & $\begin{array}{r}.012 \\
(4.223)\end{array}$ & $\begin{array}{r}.007 \\
(3.495)\end{array}$ & $\begin{array}{r}-.002 \\
(-.503)\end{array}$ & $\begin{array}{r}.024 \\
(15.590)\end{array}$ & $\begin{array}{r}.003 \\
(.507)\end{array}$ & $\begin{array}{r}.003 \\
(.566)\end{array}$ & $\begin{array}{r}.012 \\
(5.844)\end{array}$ \\
\hline
\end{tabular}


Table 2B.1

(continued)

\begin{tabular}{|c|c|c|c|c|c|c|c|c|c|c|c|c|c|c|}
\hline \multirow[b]{2}{*}{ Farameter } & \multicolumn{14}{|c|}{ Industry } \\
\hline & $\begin{array}{l}\text { Stone. Clay } \\
\& \text { Glass } \\
\text { Produtets }\end{array}$ & $\begin{array}{l}\text { Iron } \\
\& \\
\text { Stecl }\end{array}$ & $\begin{array}{l}\text { Fabricated } \\
\text { Metal } \\
\text { Products }\end{array}$ & Machinery & $\begin{array}{l}\text { Electric } \\
\text { Machinery }\end{array}$ & $\begin{array}{c}\text { Motor } \\
\text { Vehicle \& } \\
\text { Equipment }\end{array}$ & $\begin{array}{l}\text { Treanspomation } \\
\text { Equipment, } \\
\text { Except Motor }\end{array}$ & $\begin{array}{l}\text { Precision } \\
\text { lnstruments }\end{array}$ & $\begin{array}{l}\text { Miscellaneojs } \\
\text { Manufacturing }\end{array}$ & $\begin{array}{c}\text { Transportation } \\
\& \\
\text { Commmnication }\end{array}$ & $\begin{array}{l}\text { Electric Utility, } \\
\text { Gas Supply \& } \\
\text { Water Supply }\end{array}$ & $\begin{array}{c}\text { Wholesale } \\
\text { \& Retail } \\
\text { Trade }\end{array}$ & $\begin{array}{c}\text { Finance } \\
\& \\
\text { Insurance }\end{array}$ & Setrice \\
\hline$\alpha_{K}$ & $\begin{array}{r}.130 \\
(48.845)\end{array}$ & $\begin{array}{r}.092 \\
(44.968)\end{array}$ & $\begin{array}{r}.094 \\
(33.979)\end{array}$ & $\begin{array}{r}.120 \\
(44.149)\end{array}$ & $\begin{array}{r}.098 \\
(23.830)\end{array}$ & $\begin{array}{r}.112 \\
(20.575)\end{array}$ & $\begin{array}{r}.043 \\
(10.994)\end{array}$ & $\begin{array}{r}.149 \\
(26.604)\end{array}$ & $\begin{array}{r}.153 \\
(46.026)\end{array}$ & $\begin{array}{r}.171 \\
(78.090)\end{array}$ & $\begin{array}{r}.278 \\
(76.882)\end{array}$ & $\begin{array}{r}.149 \\
(58.100)\end{array}$ & $\begin{array}{r}.186 \\
(59.765)\end{array}$ & $\begin{array}{r}.430 \\
(129.970)\end{array}$ \\
\hline$\alpha_{L}$ & $\begin{array}{r}.342 \\
(96.358)\end{array}$ & $\begin{array}{r}.239 \\
(59.960)\end{array}$ & $\begin{array}{r}.376 \\
(126.698)\end{array}$ & $\begin{array}{r}.380 \\
(66.547)\end{array}$ & $\begin{array}{r}.371 \\
(105.181)\end{array}$ & $\begin{array}{r}.206 \\
(50.784)\end{array}$ & $\begin{array}{r}.345 \\
(50.987)\end{array}$ & $\begin{array}{r}.498 \\
(65.066)\end{array}$ & $\begin{array}{r}.294 \\
(61.543)\end{array}$ & $\begin{array}{r}.319 \\
(149.582)\end{array}$ & $\begin{array}{r}.150 \\
(44.945)\end{array}$ & $\begin{array}{r}.520 \\
(77.690)\end{array}$ & $\begin{array}{r}.2 \mathrm{H} \\
(51.148)\end{array}$ & $\begin{array}{r}.250 \\
(119.346)\end{array}$ \\
\hline$\alpha_{H}$ & $\begin{array}{r}.528 \\
(139.675)\end{array}$ & $\begin{array}{r}.669 \\
(159.034)\end{array}$ & $\begin{array}{r}.531 \\
(182.333)\end{array}$ & $\begin{array}{r}.500 \\
(75.034)\end{array}$ & $\begin{array}{r}.531 \\
(134.562)\end{array}$ & $\begin{array}{r}.682 \\
(104.216)\end{array}$ & $\begin{array}{r}.612 \\
(70.859)\end{array}$ & $\begin{array}{r}.353 \\
(43.445)\end{array}$ & $\begin{array}{r}.553 \\
(84.550)\end{array}$ & $\begin{array}{r}.510 \\
(265.597)\end{array}$ & $\begin{array}{r}.562 \\
(112.380)\end{array}$ & $\begin{array}{r}.331 \\
(48.761)\end{array}$ & $\begin{array}{r}.603 \\
(130.635)\end{array}$ & $\begin{array}{r}.320 \\
(81.072)\end{array}$ \\
\hline$a_{D}$ & $\begin{array}{r}-.167 \\
(-.020)\end{array}$ & $\begin{array}{r}-3754.465 \\
(-.512)\end{array}$ & $\begin{array}{r}5048.535 \\
(1.033)\end{array}$ & $\begin{array}{r}-10990.098 \\
(-1.173)\end{array}$ & $\begin{array}{r}-10809.703 \\
(-1.665)\end{array}$ & $\begin{array}{r}.0001 \\
(.501)\end{array}$ & $\begin{array}{r}.0003 \\
(.016)\end{array}$ & $\begin{array}{r}-5894.293 \\
(-.856)\end{array}$ & $\begin{array}{r}1729.229 \\
(.212)\end{array}$ & $\begin{array}{r}8332.473 \\
(1.087)\end{array}$ & $\begin{array}{r}18942.898 \\
(2.081)\end{array}$ & $\begin{array}{r}9951.582 \\
(1.213)\end{array}$ & $\begin{array}{r}44612.750 \\
(3.295)\end{array}$ & $\begin{array}{r}9306.051 \\
(2.046)\end{array}$ \\
\hline$a_{T}$ & $\begin{array}{r}-.004 \\
(-.309)\end{array}$ & $\begin{array}{r}-.002 \\
(-.172)\end{array}$ & $\begin{array}{r}.009 \\
(.864)\end{array}$ & $\begin{array}{r}.003 \\
(.178)\end{array}$ & $\begin{array}{r}.018 \\
(2.119)\end{array}$ & $\begin{array}{l}.00482 \\
(.225)\end{array}$ & $\begin{array}{r}.006 \\
(.497)\end{array}$ & $\begin{array}{r}.012 \\
(.543)\end{array}$ & $\begin{array}{r}-.003 \\
(-.129)\end{array}$ & $\begin{array}{r}.009 \\
(1.310)\end{array}$ & $\begin{array}{r}-.004 \\
(-.344)\end{array}$ & $\begin{array}{r}.010 \\
(1.739)\end{array}$ & $\begin{array}{r}.006 \\
(1.487)\end{array}$ & $\begin{array}{r}-.002 \\
(-.367)\end{array}$ \\
\hline$\beta_{k K K}$ & $\cdots$ & . . & $\begin{array}{r}-.011 \\
(-.786)\end{array}$ & . & $\ldots$ & $\begin{array}{r}-.080 \\
(-4.960)\end{array}$ & $\begin{array}{r}-.048 \\
(-4.37)\end{array}$ & $\begin{array}{r}-.020 \\
(-1.841)\end{array}$ & $\begin{array}{l}-.00494 \\
(-1.036)\end{array}$ & $\begin{array}{r}-.902 \\
(-2.701)\end{array}$ & & $\begin{array}{r}-.081 \\
(-3.472)\end{array}$ & . & . \\
\hline$\beta_{i L}$ & 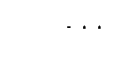 & $\begin{array}{r}-.008 \\
(-1.401)\end{array}$ & $\begin{array}{r}-.036 \\
(-2.571)\end{array}$ & . & $\begin{array}{r}-.019 \\
(-1.000)\end{array}$ & $\begin{array}{r}-.030 \\
(-1.913)\end{array}$ & $\begin{array}{r}-.002 \\
(-.518)\end{array}$ & $\begin{array}{r}-.020 \\
(-1.034)\end{array}$ & $\begin{array}{r}-.088 \\
(-4.293)\end{array}$ & $\begin{array}{r}-.119 \\
(-3.922)\end{array}$ & $\begin{array}{r}-.122 \\
(-8.713)\end{array}$ & $\begin{array}{r}-.022 \\
(-1.53 .1)\end{array}$ & & $\cdots$ \\
\hline$\beta_{M M}$ & $\ldots$ & $\begin{array}{r}-.008 \\
(-1.401)\end{array}$ & $\begin{array}{r}-.035 \\
(-1.737)\end{array}$ & . & $\begin{array}{r}-.019 \\
(-1.000)\end{array}$ & $\begin{array}{r}-.057 \\
(-1.956)\end{array}$ & $\begin{array}{r}-.069 \\
(-2.989)\end{array}$ & $\begin{array}{r}-.000002 \\
(-.009)\end{array}$ & $\begin{array}{r}-.052 \\
(-2.181)\end{array}$ & $\begin{array}{r}-.002 \\
(-.188)\end{array}$ & $\begin{array}{r}-.122 \\
(-8.713)\end{array}$ & $\begin{array}{r}-.019 \\
(-1.172)\end{array}$ & $\ldots$ & $\ldots$ \\
\hline$\beta_{D D}$ & $\begin{array}{r}333.760 \\
(.020)\end{array}$ & $\begin{array}{r}7508.832 \\
(.512)\end{array}$ & $\begin{array}{r}-10097.117 \\
(-1.033)\end{array}$ & $\begin{array}{r}21979.551 \\
(1.172)\end{array}$ & $\begin{array}{r}21618.820 \\
\quad(1.665\end{array}$ & $\begin{array}{r}-13130.848 \\
(-.501)\end{array}$ & $\begin{array}{r}-.002 \\
(-.017)\end{array}$ & $\begin{array}{r}11788.879 \\
(.856)\end{array}$ & $\begin{array}{r}-3458.634 \\
(-.212)\end{array}$ & $\begin{array}{r}-16665.172 \\
(-1.087)\end{array}$ & $\begin{array}{r}-37888.145 \\
(-2.081)\end{array}$ & $\begin{array}{r}-19903.762 \\
(-1.213)\end{array}$ & $\begin{array}{r}-89225.500 \\
(-3.295)\end{array}$ & $\begin{array}{r}-18612.191 \\
(-2.046)\end{array}$ \\
\hline
\end{tabular}




\begin{tabular}{|c|c|c|c|c|c|c|c|c|c|c|c|c|c|c|}
\hline$\beta_{T T}$ & $\begin{array}{r}-.002 \\
(-.977)\end{array}$ & $\begin{array}{r}.005 \\
(2.178)\end{array}$ & $\begin{array}{r}-.0003 \\
(-.153)\end{array}$ & $\begin{array}{l}.00103 \\
(.396)\end{array}$ & $\begin{array}{l}.0001 \\
(.050)\end{array}$ & $\begin{array}{r}.004 \\
(1.101)\end{array}$ & $\begin{array}{r}-.002 \\
(-.969)\end{array}$ & $\begin{array}{r}-.002 \\
(-.576)\end{array}$ & $\begin{array}{r}-.001 \\
(-.357)\end{array}$ & $\begin{array}{r}-.002 \\
(-1.383)\end{array}$ & $\begin{array}{r}-001 \\
(-.512)\end{array}$ & $\begin{array}{r}-.0004 \\
(-.430)\end{array}$ & $\begin{array}{r}-.002 \\
(2.929)\end{array}$ & $\begin{array}{r}-.001 \\
(-1.103)\end{array}$ \\
\hline$\beta_{L K}$ & $\cdots$ & $\ldots$ & $\begin{array}{r}.006 \\
(.592)\end{array}$ & $\ldots$ & $\ldots$ & $\begin{array}{r}.027 \\
(2.527)\end{array}$ & $\begin{array}{r}-.010 \\
(-1.057)\end{array}$ & $\begin{array}{r}.020 \\
(1.721)\end{array}$ & $\begin{array}{r}.021 \\
(2.088)\end{array}$ & $\begin{array}{r}.104 \\
(3.569)\end{array}$ & . & $\begin{array}{r}.042 \\
(2.675)\end{array}$ & & $\cdots$ \\
\hline$\beta_{M K}$ & $\ldots$ & . & $\begin{array}{r}.005 \\
(.336)\end{array}$ & $\ldots$ & $\ldots$ & $\begin{array}{r}.0535 \\
(2.856)\end{array}$ & $\begin{array}{r}.058 \\
(4.267)\end{array}$ & $\begin{array}{l}.0002 \\
(.017)\end{array}$ & $\begin{array}{r}-.016 \\
(-2.901)\end{array}$ & $\begin{array}{r}-.013 \\
(-.801)\end{array}$ & . & $\begin{array}{r}.039 \\
(1.906)\end{array}$ & $\begin{array}{l}\cdots \\
\ldots\end{array}$ & $\begin{array}{l}\ldots \\
\ldots\end{array}$ \\
\hline$\beta_{M L}$ & $\ldots$ & $\begin{array}{r}.008 \\
(1.401)\end{array}$ & $\begin{array}{r}.030 \\
(2.481)\end{array}$ & $\ldots$ & $\begin{array}{r}.0194 \\
(1.000)\end{array}$ & $\begin{array}{l}.0036 \\
(.200)\end{array}$ & $\begin{array}{r}.011 \\
(.903)\end{array}$ & $\begin{array}{r}-.0002 \\
(-.017)\end{array}$ & $\begin{array}{r}.068 \\
(3.057)\end{array}$ & $\begin{array}{r}.016 \\
(1.194)\end{array}$ & $\begin{array}{r}.122 \\
(8.713)\end{array}$ & $\begin{array}{r}-.020 \\
(-3.387)\end{array}$ & $\ldots$ & $\ldots$ \\
\hline$\beta_{D K}$ & $\begin{array}{r}.0212 \\
(2.783)\end{array}$ & $\begin{array}{r}.046 \\
(10.845)\end{array}$ & $\begin{array}{r}-.001 \\
(-.076)\end{array}$ & $\begin{array}{r}.020 \\
(3.396)\end{array}$ & $\begin{array}{r}.064 \\
(12.958)\end{array}$ & $\begin{array}{r}.024 \\
(1.410)\end{array}$ & $\begin{array}{r}.117 \\
(8.341)\end{array}$ & $\begin{array}{r}-.051 \\
(-3.172)\end{array}$ & $\begin{array}{r}-.094 \\
(-6.266)\end{array}$ & $\begin{array}{r}-.092 \\
(-2.206)\end{array}$ & $\begin{array}{r}.066 \\
(4.991)\end{array}$ & $\begin{array}{r}.071 \\
(3.338)\end{array}$ & $\begin{array}{r}.196 \\
(27.958)\end{array}$ & $\begin{array}{r}-.127 \\
(-15.222)\end{array}$ \\
\hline$\beta_{D L}$ & $\begin{array}{c}-.155 \\
(-30.647)\end{array}$ & $\begin{array}{r}-.165 \\
(-16.727)\end{array}$ & $\begin{array}{r}-.060 \\
(-2.644)\end{array}$ & $\begin{array}{r}-.169 \\
(-13.343)\end{array}$ & $\begin{array}{r}-.170 \\
(-5.908)\end{array}$ & $\begin{array}{r}-.030 \\
(-1.190)\end{array}$ & $\begin{array}{r}-.113 \\
(-7.114)\end{array}$ & $\begin{array}{r}-.257 \\
(-9.358)\end{array}$ & $\begin{array}{r}.012 \\
(.456)\end{array}$ & $\begin{array}{r}.280 \\
(6.475)\end{array}$ & $\begin{array}{r}.172 \\
(9.670)\end{array}$ & $\begin{array}{r}-.162 \\
(-7.036)\end{array}$ & $\begin{array}{r}.123 \\
(17.046)\end{array}$ & $\begin{array}{r}-.051 \\
(-9.888)\end{array}$ \\
\hline$\beta_{D M}$ & $\begin{array}{r}.134 \\
(23.953)\end{array}$ & $\begin{array}{r}.119 \\
(11.360)\end{array}$ & $\begin{array}{r}.061 \\
(3.093)\end{array}$ & $\begin{array}{r}.149 \\
(13.741)\end{array}$ & $\begin{array}{r}.105 \\
(3.699)\end{array}$ & $\begin{array}{r}.006 \\
(.199)\end{array}$ & $\begin{array}{r}-.005 \\
(-.186)\end{array}$ & $\begin{array}{r}.308 \\
(13.231)\end{array}$ & $\begin{array}{r}.081 \\
(2.764)\end{array}$ & $\begin{array}{r}-.188 \\
(-10.091)\end{array}$ & $\begin{array}{r}-.238 \\
(-11.395)\end{array}$ & $\begin{array}{r}.090 \\
(5.770)\end{array}$ & $\begin{array}{r}-.319 \\
(-35.387)\end{array}$ & $\begin{array}{r}.178 \\
(22.825)\end{array}$ \\
\hline$\beta_{T K}$ & $\begin{array}{r}-.003 \\
(-6.632)\end{array}$ & $\begin{array}{r}-.003 \\
(-8.980)\end{array}$ & $\begin{array}{r}.001 \\
(1.477)\end{array}$ & $\begin{array}{r}-.002 \\
(-5.314)\end{array}$ & $\begin{array}{r}-.001 \\
(-1.616)\end{array}$ & $\begin{array}{r}-.004 \\
(-4.591)\end{array}$ & $\begin{array}{r}-.001 \\
(-1.368)\end{array}$ & $\begin{array}{r}-.006 \\
(-5.394)\end{array}$ & $\begin{array}{r}.001 \\
(1.435)\end{array}$ & $\begin{array}{r}.003 \\
(1.876)\end{array}$ & $\begin{array}{r}-.006 \\
(-10.327)\end{array}$ & $\begin{array}{r}.002 \\
(3.018)\end{array}$ & $\begin{array}{r}-.004 \\
(-9.536)\end{array}$ & $\begin{array}{r}-.002 \\
(-3.170)\end{array}$ \\
\hline$\beta_{\tau L}$ & $\begin{array}{r}-.0001 \\
(-1.543)\end{array}$ & $\begin{array}{r}.0002 \\
(.320)\end{array}$ & $\begin{array}{r}-.002 \\
(-3.201)\end{array}$ & $\begin{array}{r}-.831 \\
(-.516)\end{array}$ & $\begin{array}{l}.0003 \\
(.390)\end{array}$ & $\begin{array}{r}.001 \\
(.824)\end{array}$ & $\begin{array}{r}-.001 \\
(-2.689)\end{array}$ & $\begin{array}{l}-.0002 \\
(-.139)\end{array}$ & $\begin{array}{r}-.003 \\
(-3.076)\end{array}$ & $\begin{array}{r}-.003 \\
(-2.339)\end{array}$ & $\begin{array}{r}-.008 \\
(-11.689)\end{array}$ & $\begin{array}{r}.002 \\
(2.400)\end{array}$ & $\begin{array}{r}.002 \\
(4.251)\end{array}$ & $\begin{array}{r}-.003 \\
(12.375)\end{array}$ \\
\hline $\boldsymbol{\beta}_{\tau M}$ & $\begin{array}{r}.003 \\
(6.406)\end{array}$ & $\begin{array}{r}.003 \\
(5.074)\end{array}$ & $\begin{array}{r}.001 \\
(2.336)\end{array}$ & $\begin{array}{r}.002 \\
(4.983)\end{array}$ & $\begin{array}{r}.001 \\
(.767)\end{array}$ & $\begin{array}{r}.003 \\
(3.328)\end{array}$ & $\begin{array}{r}.002 \\
(2.381)\end{array}$ & $\begin{array}{r}.006 \\
(5.757)\end{array}$ & $\begin{array}{r}.003 \\
(2.058)\end{array}$ & $\begin{array}{r}.001 \\
(.682)\end{array}$ & $\begin{array}{r}.014 \\
(14.432)\end{array}$ & $\begin{array}{r}-.004 \\
(-8.196)\end{array}$ & $\begin{array}{r}.003 \\
(10.816)\end{array}$ & $\begin{array}{r}-.002 \\
(-4.236)\end{array}$ \\
\hline$\beta_{T D}$ & $\begin{array}{r}.016 \\
(6.500)\end{array}$ & $\begin{array}{r}.018 \\
(7.748)\end{array}$ & $\begin{array}{r}.015 \\
(9.390)\end{array}$ & $\begin{array}{r}.022 \\
(7.503)\end{array}$ & $\begin{array}{r}.026 \\
(10.492)\end{array}$ & $\begin{array}{r}-.002 \\
(-.537)\end{array}$ & $\begin{array}{r}.029 \\
(5.079)\end{array}$ & $\begin{array}{r}.015 \\
(5.238)\end{array}$ & $\begin{array}{r}.019 \\
(5.296)\end{array}$ & $\begin{array}{r}.022 \\
(6.976)\end{array}$ & $\begin{array}{r}.014 \\
(4.283)\end{array}$ & $\begin{array}{r}-.003 \\
(-1.053)\end{array}$ & $\begin{array}{r}.027 \\
(6.744)\end{array}$ & $\begin{array}{r}-.011 \\
(-6.290)\end{array}$ \\
\hline
\end{tabular}




\section{Notes}

1. The share elasticity was introduced by Christensen, Jorgenson, and Lau (1971, 1973) and by Samuelson (1973).

2. Share elasticities were first employed as constant parameters of an econometric model of producer behavior by Christensen, Jorgenson, and Lau (1971, 1973). Constant share elasticities and biases of technical change are employed by Jorgenson and Fraumeni (1981); Jorgenson (1983, 1984), and Kuroda, Yoshioka, and Jorgenson (1984). Binswanger (1974a, 1974b, 1978a) uses a different definition of biases of technical change in parameterizing an econometric model with constant share elasticities.

3. Alternative definitions of biases of technical change are compared by Binswanger (1978b).

4. Biases of the difference in technology were introduced by Binswanger (1974a, $1974 b, 1978 a)$.

5. Biases of technical change with respect to the difference of technology were introduced by Jorgenson and Nishimizu (1978) in the context of a bilateral model of production for Japan and the United States at the aggregate level. This model was extended to the sectoral level by Jorgenson and Nishimizu (1981).

6. The difference of the difference of technology was introduced by Jorgenson and Nishimizu (1978, 1981).

7. This approach to global concavity was originated by Jorgenson and Fraumeni (1981). The Cholesky factorization was first employed in imposing local concavity restrictions by Lau (1978).

8. Alternative stochastic specifications for econometric models of production are discussed by Fuss, McFadden, and Mundlak (1978). Additional detail on econometric methods for modeling producer behavior is given by Jorgenson (1986).

\section{References}

Binswanger, H. P. 1974a. A cost-function approach to the measurement of elasticities of factor demand and elasticities of substitution. American Journal of Agricultural Economics 56, no. 2 (May):377-86.

$1974 \mathrm{~b}$. The measurement of technical change biases with many factors of production. American Economic Review 64, no. 5, (December):964-76.

- 1978a. Induced technical change: Evolution of thought. In Induced innovation, ed. H. P. Binswanger and V. W. Ruttan, 13-43. Baltimore: Johns Hopkins University Press.

$1978 \mathrm{~b}$. Issues in modeling induced technical change. In Induced innovation, ed. H. P. Binswanger and V. W. Ruttan, 128-63. Baltimore: Johns Hopkins University Press.

Christensen, L. R., D. W. Jorgenson, and L. J. Lau. 1971. Conjugate duality and the transcendental logarithmic production function. Econometrica 39, no. 4 (July):25556.

1973. Transcendental logarithmic production frontiers. Review of Economics and Statistics 55, no. 1 (February):28-45.

Fuss, M., D. McFadden, and Y. Mundlak. 1978. A survey of functional forms in the economic analysis of production. In Production Economics, ed. M. Fuss and D. McFadden, 1:219-68. Amsterdam: North-Holland. 
Jorgenson, D. W. 1983. Modeling production for general equilibrium analysis. Scandinavian Journal of Economics 85 (2):101-12.

1984. The role of energy in productivity growth. In International comparisons of productivity and causes of the slowdown, ed. J. W. Kendrick, 279-323. Cambridge: Ballinger.

- 1986. Econometric methods for modeling producer behavior. In Handbook of econometrics, ed. Z. Griliches and M. D. Intriligator, 3:1841-1915. Amsterdam: North-Holland.

Jorgenson, D. W., and B. M. Fraumeni. 1981. Relative prices and technical change. In Modeling and measuring natural resource substitution, ed. E. R. Berndt and B. C. Field, pp. 17-47. Cambridge, Mass.: MIT Press.

Jorgenson, D. W., M. Kuroda, and M. Nishimizu. 1987. Japan-U.S. industry-level productivity comparisons, 1960-1979. Journal of the Japanese and International Economies 1, no. I (March): 1-30.

Jorgenson, D. W., and J.-J. Laffont. 1974. Efficient estimation of non-linear simultaneous equations with additive disturbances. Annals of Social and Economic Measurement 3, no. 4 (October):615-40.

Jorgenson, D. W., and M. Nishimizu. 1978. U.S. and Japanese economic growth, 1952-1974: An international comparison. Economic Journal 88, no. 352, (December):707-26.

. 1981. International differences in levels of technology: A comparison between U.S. and Japanese industries. In International roundtable conference proceedings. Tokyo: Institute of Statistical Mathematics.

Kuroda, M., K. Yoshioka, and D. W. Jorgenson. 1984. Relative price changes and biases of technical change in Japan. Economic Studies Quarterly 35, no. 2, (August): 116-38.

Lau, L. J. 1978. Testing and imposing monotonicity, convexity and quasi-convexity constraints, In Production economics, ed. M. Fuss and D. McFadden, 1:409-53. Amsterdam: North-Holland.

Samuelson, P. A. 1973. Relative shares and elasticities simplified: Comment. American Economic Review 63, no. 4 (September):770-71. 